was born on November 4. I am an election baby. I was born on a Wednesday, but in the year I was born, there was not a U.S. general election. Those only happen on Nuggets for the Future

\author{
Susan J. Beck, 2009-10 President \\ of the Reference and User Services \\ Association, is Head of Public Services, \\ Paul Robeson Library, Rutgers, \\ the State University of New Jersey, \\ Camden; e-mail: susan.beck@rutgers. \\ edu.
}

the Tuesday after the first Monday of November from November 2 through November 8 in even-numbered years. ${ }^{1}$ I was born in an odd year. Since the turn of the twenty-firstcentury, the U.S. general election has fallen on my birthday twice already. I cannot think of elections without thinking of my birthday.

As a child, one form of free and educational entertainment in which my family engaged, when my birthday was on election day, was watching the election returns come in at the Huron County (Ohio) Courthouse. We did this after a celebratory birthday dinner at Kentucky Fried Chicken. The courthouse is a majestic building with an imposing bell tower that sits right in the center of downtown Norwalk, Ohio. You can see for yourself in Wikipedia or just Google it to look at other courthouse images. ${ }^{2}$ We climbed the imposing steps to the second floor to watch the flurry of activity surrounding the elections. It was all very exciting - all this fuss just for my birthday. I remember the election board officials handed out small patriotic tokens like Ohio flags to children and the party officials gave out leftover buttons and rulers with their party's campaign slogans. I still have a wooden ruler from the 1960 election. I also seem to remember donuts — and cider-even though I really associate those with the Halloween parade a few days before. Maybe they were just leftover, too.

When I was young, I wanted to be a senator. Instead, I am proud to say I became the president of RUSA. There was an election involved. I have both a bachelor's and master's degree in political science-all because I was born in the first week of November. It's funny how when you were born affects who you become. I am a Scorpio. According to one astrological website, "the curiosity of Scorpios is immeasurable, which may be why they are such adept investigators. These folks love to probe and know how to get to the bottom of things." 3

Ah, so this is why I became a reference librarian. It also is probably why it takes me so long to write these columnscuriosity gets the best of me and the Web provides so many fascinating distractions. Case in point: For this editorial, I actually looked up the biography of the architect of the Huron County Courthouse, Vernon Redding, to discover that he also built a number of Carnegie Libraries in Ohio. ${ }^{4}$ I digress.

So, as you can see, elections and voting have always been very important to me.

This issue of RUSQ will come out just before the 2010 ALA elections. So I want to take this opportunity to encourage 
you to vote. One of the privileges and, yes, responsibilities of membership in RUSA is to vote. Effective governance of associations requires the participation of its members. Voting provides us with the opportunity to shape our association. Even if you are not able to participate on RUSA committees or attend conferences, our election is one place where you can actively participate and make a difference. Your vote does count. I can't tell you how many elections I have seen in RUSA where elections were won or lost by just one vote, much to the amazement, incredulity, and disappointment of the candidates. In the 2009 RUSA elections, there were three very tight races. One candidate won by one vote for a memberat-large position. Two chair positions were won by less than a 3 percent margin. This illustrates that the two candidates were well matched, but it also demonstrates that each vote is important. Our electoral participation rate as a division is 23.9 percent. This is comparable to ALA's participation rate of 23.4 percent. ${ }^{5}$ See table 1 to see how our members vote in each of our division's sections.

The point is, I expect you to vote in the next election. You will select members to represent your views and opinions. You will select the leadership of RUSA and its sections. An election is one of the most important participatory events in any association, so vote and let your voice be heard. Participation is what this is all about!

I am going to quickly describe the candidate selection process in case you are unfamiliar with it. One of the first things one does as the president-elect or as a section vicechair is to appoint the next Nominating Committee chair. This process is completed by November. The Nominating Committees recruit a slate of candidates for each open elective position. The slates are finalized at the ALA Annual Conference and the nominees submitted to the RUSA office by September 15 for the spring election. Candidates are asked to submit biographical information, including data about their education and professional positions, as well as to describe their ALA activities and accomplishments. The candidates also are asked to provide a statement about their professional concerns.

Voting in ALA elections can be time consuming and even intimidating to the new voter. I am a member of two ALA divisions, all six RUSA sections, and a roundtable, so it takes me awhile. I love the new electronic voting, which lets me go vote for one position at a time without having to complete the entire ballot when I am inevitably interrupted.

What kind of voter are you? Are you intimidated by the lengthy ALA ballots? Are you the voter who quickly zeros in on your choice, makes your selection, saves them and exits out of there as fast as you can, perhaps seldom reading the candidate's biography and statement of concerns? Or are you the voter who simply must learn where the candidate is from, where they worked, and what committees they have served on? Do you want to discover whether you have worked with the person, or perhaps know someone who has worked with the person, or ever lived in the same state-you see what I mean? Guess which type of voter I am? Yes! I openly admit it-I love to read everything about each candidate!

You can learn a lot about a person and how they think by reading their statements. You can find out what the candidate values about our association, what they believe the association should be doing, how they think RUSA can best help meet members' needs, and what they think are the most important benefits the association offers its members. What are the important issues facing the profession, the association, and their specialized section? What is important to the candidate? How do they perceive the needs of our specialties in our profession? What has their participation in RUSA meant to them?

For the last few years I have been selectively collecting RUSA candidate's statements at election time, not quite knowing just what I would be doing with them, but thinking they would be interesting to analyze. ${ }^{6}$ So, this is the first of two columns examining the statement of concerns from 105 candidates who have run for an elected position in RUSA in the past three years (2007-09). Since 2007, 109 members have run for an elective office. These include every candidate for RUSA president, board of directors, councilor, chair, secretary, and member at large. Of the 109 candidates, 105 (96.3 percent) completed the statement of concern portion of the ballot. In the future I hope all the candidates will think that it is important to provide this information.

This column examines issues reTable 1. RUSA Voting Behavior in the 2009 Elections

\begin{tabular}{lccc}
\hline RUSA Sections & Membership* & Eligible Ballots ** & Percentage Voting \\
RUSA & 4,133 & 983 & 23.7 \\
BRASS & 1,040 & 252 & 24.2 \\
CODES & 1,598 & 413 & 25.8 \\
History Section & 817 & 174 & 21.2 \\
MARS & 1,421 & 344 & 24.2 \\
RSS & 1,830 & 448 & 24.4 \\
STARS & 813 & 195 & 23.9 \\
\hline
\end{tabular}

* Based on the April 2009 membership report

** This is the number of ballots returned from RUSA members lated to association participation. What are the candidates' expressed professional values? What RUSA programs, products, and services do the candidates believe provide the most value to the membership? What are the important issues related to governance of their section, RUSA, and ALA? How can these views affect the services we offer our members?

The next column will analyze the candidate statements to determine implications for our strategic plan- 


\section{FROM THE PRESIDENT OF RUSA}

I welcome your ideas as to how we can best make RUSA more responsive to your needs. Please feel free to email me with any concerns, suggestions, or solutions at susan.beck@rutgers.edu. ning process. What do the candidates believe to be the most important issues facing the profession today? What are our challenges? A few of the issues identified include the recruitment and retention of members, the changing nature of member participation, and relevancy in the age of Google.

Our candidates do not have all the answers. But, what they do tell us through their statements is their perceptions of the state of the profession and what they think they can bring to the association. Their concerns can help guide the discussion of our future. After all, in every election, the winners become the RUSA leaders of today.

When I began this study, in my incorrigible curiosity, there were many things I wanted to know. But I fundamentally wanted to discover what I could learn from the prospective leaders of our association about their vision of our future and their perceptions of RUSA's role in their professional lives. This is a conversation with our candidates. Anonymous quotations represent the hopes, values, and concerns of our leaders.

Here is what I learned.

\section{PROFESSIONAL VALUES}

RUSA's candidates for office are probably very much like you and me. They believe in the essential core values that guide our profession. Their statements include a commitment to provide access to information, a commitment to diversity, attention to confidentiality and privacy concerns, a belief in educating both themselves and their users, and a desire to encourage lifelong learning. They care about their professionalism, their social responsibilities and the quality of services they provide. They show a pride in our profession and a sense of satisfaction in what they do. One candidate said,

I am honored to be considered for president of an organization that I have long been active in and that has formed so much of my professional identity.

Another candidate declared,

I owe much of my career to RUSA_-professional work; knowledge I have gained from colleagues; contacts that have helped locate rare items and shared their reference expertise.

Reading through the candidates' statements about how and why they value the profession is like listening to the refrain of a love ballad. It is remarkable to hear our members share how positive, energetic, and inspired they feel about our profession.

\section{MEMBERSHIP BENEFITS}

In my last column, I listed what I perceived to be the benefits of membership in RUSA during a recession. Those were my opinions. I looked at all the great things we do and without hesitation declared them as association benefits (and of course I do still believe that they are benefits). Now I can say without fear of denial that our candidates share my views about our membership benefits.

Because I was looking at three years of data, I wanted to see if there were any major differences across the years in terms of what the candidates identified and considered to be the member's greatest benefits.

As to be expected, professional development was mentioned every year. The terminology differed, but the meaning was the same. The candidates were interested in having RUSA provide professional development activities and believed that professional development is one of the primary responsibilities of a professional association. I find it interesting that the mentions of professional development activities steadily increased over the three years (seven mentions in 2007, eleven in 2008, and fifteen in 2009).

I still believe that the most valuable benefit we provide is the opportunity to network and share experiences with our colleagues. I identified forty-five instances of the concept networking over the three years. As I looked over the statements, there were so many wonderful quotes I wanted to share with you. Here are some statements I believe exemplify the importance of networking to our members:

My professional concerns are also about branching out to interact with my peers at other institutions to share similar ideas and concerns about our wonderful, dynamic profession.

And this:

I find the RUSA HS [History Section] to be a wonderful way to increase my knowledge in order to be more effective. I am very grateful for the interchanges with my colleagues across the country; I feel inspired and grateful.

Another candidate expressed the necessity of sharing:

As we share our resources, we also need to share our information, processes, and policies so that all have access to materials. RUSA STARS facilitates that discussion and provides a forum for sharing knowledge and expertise in resource sharing.

But this is my all-time favorite-I also coded this as an example of self-confidence:

I have served on committees in which I learned from many of the most talented librarians in the country to think broadly about professional issues and I also 
learned that my participation and opinions are important.

The candidates also speak of our tradition of developing resources and making them available. RUSA is well known for its creation of professional tools, like our Standards and Guidelines and the websites like MARS' Best Free Reference Web Sites 2009 and the History Section's Using Primary Sources on the Web. ${ }^{7}$ The terminology describing these efforts has changed over the years. We used to speak about paper publications; now we create content, but we still develop resources and make them available.

One candidate stated,

I see the RSS section as a fun and exciting group of people that are truly interested in creating tools that advance the profession and help librarians do their jobs better.

Another said,

Library organizations such as MARS can be very helpful for librarians seeking to quickly access reliable, accurate information. In providing tools and resources for libraries we help promote lifelong learning and foster a feeling of satisfaction for our library patrons.

BRASS is the section that I most associate with a mentoring program. When young members get extra attention and support they become the future leaders, as in the case of this librarian:

I feel fortunate to have become involved with BRASS early in my career. I think one thing we always want to do with BRASS is help our new members learn about our organization and encourage them to become active members.

The candidates also cited the value of sections' awards and the important work of all our committee members.

\section{GOVERNANCE ISSUES}

The candidates spoke of governance issues. They primarily focused on their desire to make a difference in the sections, but they also expressed expectations of RUSA leadership, RUSA staff, and ALA. The candidates envisioned their roles as facilitators of committee work, section advocates, and as representatives of the section's members. They encouraged transparency within their section and within RUSA, and they emphasized the improvement of interactive communication between their members, section, and the RUSA board. way:

One candidate running for a section chair put it this

If I were to be in a leadership role with this group, I see my role as building on this tradition of being a key professional resource for those doing reference and user services, and work to provide the support committees need to help define and expand the evolving role of the profession to meet the new needs and challenges inherent in the changing information technology landscape.

One candidate saw her primary responsibility as this:

To best represent and communicate the needs and interests of other CODES members. . . . As a CODES member-at-large I will work tirelessly to keep in contact with the section members.

Another CODES candidate said it like this:

It's a matter of listening to both ends of the pipeline, e.g., the CODES board and the RUSA executive committee, and conveying information both mundane and important to those who need it.

A BRASS candidate expressed similar sentiments:

I will reach out to all members of BRASS to hear their concerns and hopes for the section and will work to implement positive change.

Another candidate addressed the importance and challenges of transparency and inclusiveness in an organization:

RUSA RSS should do its best to make itself as transparent and inclusive as possible, especially to newer librarians or those uninitiated to the inner workings of ALA. Communication and transparency are easy now with newer technologies, but we must have the will to invite participation of all sorts, both to attract new members to revitalize the association that has benefited so many of us as well as share those benefits with other librarians.

\section{RUSA'S ROLE}

The candidates encouraged RUSA to use technology to communicate more effectively, giving members a fast and effortless way to voice their concerns and share ideas.

One candidate said,

I believe one of the roles of professional associations is to be a support for the many new librarians.

And another said,

The active success of RUSA sections and committees is critical to our mission to inform and inspire librarians 


\section{FROM THE PRESIDENT OF RUSA}

and staff in the endeavor of creating forward thinking information and learning environments.

One candidate had this to say about the responsibilities and expectations of both RUSA and ALA:

Together ALA and RUSA can work towards better pay, promote professional standards, and uphold our core values. RUSA, with the help of its members, must identify and develop dynamic and sustainable ways to assist us professionally. We need a variety of professional development and membership opportunities so that we and our library communities benefit from our active interaction with RUSA and ALA.

Others expressed very similar opinions:

[RUSA should] work to provide the support committees need to help define and expand the evolving role of the profession to meet the new needs and challenges inherent in the changing information technology landscape.

We depend upon the support of ALA and RUSA to find solutions and make involvement in the profession both essential and possible.

Now you can see the benefit to examining candidates' statements. I hope in the future that all candidates take the time to tell you, the voters, what is on their mind. And if they don't, shame on them. Don't vote for them. When voting, pay attention to their vision for RUSA and the future of our profession. Read the candidate's statements.

This spring a colleague called as I was knee deep in RUSA appointments and writing my first RUSQ column to ask me to run for the faculty chair in our library system. This is no small task in an organization the size of ours. My immediate response was, "Do you know how busy I am right now?" She came right back with, "Of course, I know how busy you are, everybody is busy, but it's your turn to run for chair."

She delivered a very compelling argument. She continued by saying something to the effect that whether I liked it or not, or whether I wanted the added responsibilities or not-that it was simply just my turn. Somebody has to do it. I had not run for faculty chair in a number of years, and I understood that she was right. As professionals we do have a responsibility to actively participate in the governance of our organizations. It was only right as a faculty member to take my turn.

As a candidate, I set one condition. I would not run unopposed. In large organizations it is only reasonable to provide a choice of candidates. I believe this is just as true for RUSA. We too are a large association with many dedicated and, yes, busy members. Have you ever considered running for a RUSA office? I hope you will someday. After all, it just might be your turn. You are an important part of our future.

Now back to the Rutgers Library Faculty elections. There were three worthy candidates who ran for faculty chair this year. I lost. Losers are important and necessary participants, too.

\section{References and Notes}

1. Statutes at Large, 28th Congress, 2nd Session, 721. As cited in Wikipedia contributors, "Election Day (United States)," Wikipedia, The Free Encyclopedia, http://en.wikipedia.org/wiki/Election_Day_ (United_States) (accessed July 15, 2009).

2. Wikipedia contributors, "Huron County Courthouse and Jail," Wikipedia, The Free Encyclopedia, http://en.wikipedia.org/wiki/ Huron_County_Courthouse_and_Jail (accessed July 18, 2009).

3. "Scorpio," www.astrology.com/allaboutyou/sunsigns/scorpio.html (accessed July 24, 2009).

4. Abraham J. Baughman, History of Richland County, Ohio, from 1808 to 1908 (Chicago: S.J. Clarke, 1908): 954-56, Google Books, www google.book.com, s.v. "History of Richland County, Ohio, from 1808 to 1908" (accessed July 29, 2009).

5. As a comparison, in the ALA 2009 election: 13,128 members voted of the 56,069 eligible voters, or 23.4 percent of ALA members participated in the elections. ALA figures courtesy of JoAnne Kempf (jkempf@ala.org), Director, Office of ALA Governance.

6. When I decided to analyze three years of data, the RUSA office staff provided me with a complete set of ballots for each RUSA section. I was then able to massage the data and convert them into text files and upload them into a qualitative content analysis program called ATLAS.ti (www.atlasti.com). Once in ATLAS.ti, I coded all of the statements and then synthesized the results.

7. Reference and User Services Association, Machine-Assisted Reference Section, MARS Best Free Websites 2009, www.ala.org/ala/ mgrps/divs/rusa/sections/mars/marspubs/marsbestfreewebsites/ marsbestfree2009.cfm (accessed July 29, 2009); Reference and User Services Association, History Section, Using Primary Sources on the Web, www.ala.org/ala/mgrps/divs/rusa/sections/history/ resources/pubs/usingprimarysources/index.cfm (accessed July 29, 2009). 